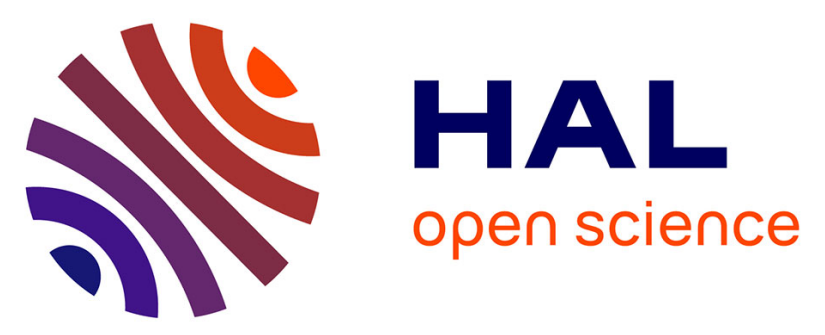

\title{
Biochemical characterization and modulation of LH/CG-receptor during human trophoblast differentiation.
}

Guillaume Pidoux, Pascale Gerbaud, Vassilis Tsatsaris, Olivier Marpeau, Fatima Ferreira, Geri Meduri, Jean Guibourdenche, Josette Badet, Danièle

Evain-Brion, Jean-Louis Frendo

\section{To cite this version:}

Guillaume Pidoux, Pascale Gerbaud, Vassilis Tsatsaris, Olivier Marpeau, Fatima Ferreira, et al.. Biochemical characterization and modulation of LH/CG-receptor during human trophoblast differentiation.: LH/CG-R in human trophoblast differentiation.. Journal of Cellular Physiology, 2007, 212 (1), pp.26-35. 10.1002/jcp.20995 . inserm-00116966

\section{HAL Id: inserm-00116966 https://www.hal.inserm.fr/inserm-00116966}

Submitted on 4 Sep 2009

HAL is a multi-disciplinary open access archive for the deposit and dissemination of scientific research documents, whether they are published or not. The documents may come from teaching and research institutions in France or abroad, or from public or private research centers.
L'archive ouverte pluridisciplinaire HAL, est destinée au dépôt et à la diffusion de documents scientifiques de niveau recherche, publiés ou non, émanant des établissements d'enseignement et de recherche français ou étrangers, des laboratoires publics ou privés. 


\section{BIOCHEMICAL CHARACTERIZATION AND MODULATION OF LH/CG - RECEPTOR DURING HUMAN TROPHOBLAST DIFFERENTIATION.}

Guillaume Pidoux $^{1 \S}$, Pascale Gerbaud ${ }^{1 \S}$, Vassilis Tsatsaris ${ }^{1,4}$, Olivier Marpeau ${ }^{1}$, Fatima

Ferreira $^{1}$, Geri Meduri ${ }^{2}$, Jean Guibourdenche ${ }^{1,3}$, Josette Badet ${ }^{1}$, Danièle Evain-Brion ${ }^{1}$ and Jean-Louis Frendo ${ }^{1,5^{*}}$.

${ }^{1}$ INSERM, U767,Université Paris 5, Paris, F-75006 France; ${ }^{2}$ INSERM, U693, Le Kremlin-Bicêtre, F94276 France; ${ }^{3}$ CHU Paris, Hôpital Robert Debré, Service d'Hormonologie, Paris, F-75019 France;

${ }^{4}$ AP-HP, Hôpital Cochin, Maternité Port-Royal, Paris, F-75014 France; ${ }^{5}$ CNRS, Paris, F-75006 France.

$\S$ These two authors contributed equally to the work.

Correspondence to: Jean-Louis Frendo, INSERM U767, Faculté de Pharmacie, 4 Avenue de l'Observatoire, 75270 Paris, France. E-mail: jean-louis.frendo@univ-paris5.fr

Running title: LH/CG-R in human trophoblast differentiation.

Key words: hCG, hPL, placenta, cytotrophoblast, syncytiotrophoblast, cell fusion.

6 text figures and 1 table 


\begin{abstract}
Due to the key role of the human chorionic gonadotropin hormone (hCG) in placental development, the aim of this study was to characterize the human trophoblastic luteinizing hormone/chorionic gonadotropin receptor (LH/CG-R) and to investigate its expression using the in

4 vitro model of human cytotrophoblast differentiation into syncytiotrophoblast. We confirmed by in 5 situ immunochemistry and in cultured cells, that LH/CG-R is expressed in both villous 6 cytotrophoblasts and syncytiotrophoblasts. However, LH/CG-R expression decreased during 7 trophoblast fusion and differentiation, while the expression of hCG and hPL (specific markers of 8 syncytiotrophoblast formation) increased. A decrease in LH/CG-R mRNA during trophoblast 9 differentiation was observed by means of semi-quantitative RT-PCR with two sets of primers. A 10 corresponding decrease $(\sim 60 \%)$ in LH/CG-R protein content was shown by western-blot and 11 immunoprecipitation experiments. The amount of the mature form of LH/CG-R, detected as a 90-kDa 12 band specifically binding ${ }^{125} \mathrm{I}-\mathrm{hCG}$, was lower in syncytiotrophoblasts than in cytotrophoblasts. This 13 was confirmed by Scatchard analysis of binding data on cultured cells. Maximum binding at the cell 14 surface decreased from 3511 to about 929 molecules/seeded cells with a $\mathrm{Kd}$ of $0.4-0.5 \mathrm{nM}$. 15 Moreover, on stimulation by recombinant hCG, the syncytiotrophoblast produced less cyclic AMP 16 than cytotrophoblasts, indicating that LH/CG-R expression is regulated during human villous 17 trophoblast differentiation.
\end{abstract}


Human chorionic gonadotropin (hCG) belongs to a family of glycoprotein hormones, which includes lutropin ( $\mathrm{LH})$, thyrotropin (TSH) and follitropin (FSH). These hormones composed of two non-covalently linked subunits, alpha $(\alpha)$ and beta $(\beta)$, are active on bicatenary form. The $\alpha$-subunit is common to all glycoprotein hormones, whereas the $\beta$-subunits confer the hormonal specificity (Pierce and Parsons, 1981). Alpha hCG is encoded by a single gene and BhCG by six genes, one of which, CGß55, is predominantly expressed in the placenta (Bo and Boime, 1992). HCG is essential for the initiation and maintenance of early pregnancy. After implantation, hCG is produced by the placenta and mainly by the trophoblast (Hoshina et al., 1985; Kliman et al., 1986; Muyan and Boime, 1997, Handschuh et al., 2006). It is used as a diagnostic marker of pregnancy.

The human placenta is characterized by extensive invasion of the trophoblast in the maternal uterus, creating direct trophoblast contact with maternal blood (haemochorial placentation). In early pregnancy, mononuclear cytotrophoblasts $(\mathrm{CT})$ proliferate and invade the maternal endometrium to form the anchoring villi. (Aplin, 1991). Cytotrophoblasts also differentiate into a multinucleated continuous layer known as the syncytiotrophoblast (ST). This cell layer, which covers the chorionic villi, is bathed by maternal blood in the intervillous spaces from early gestation (Richard, 1961; Midgley et al., 1963; Boyd and Hamilton, 1970; Benirschke and Kaufmann, 2000). This syncytiotrophoblast is multifunctional, but its primary functions are exchange of oxygen, nutriments, removal of waste products and hormone production. The syncytiotrophoblast secretes hCG in large amounts, directly into the maternal blood bathing the chorionic villi in the intervillous space.

The mechanisms underlying villous trophoblast differentiation remain largely to be explored. Syncytiotrophoblast formation in vivo and in vitro arises from villous cytotrophoblast fusion and differentiation. Several factors modulate villous trophoblast differentiation, including EGF (epidermal growth factor) and EGF receptor expression (Morrish et al., 1987; Alsat et al., 1993), hypoxia (Alsat et al., 1996), cAMP-dependent protein kinase (PKA) (Keryer et al., 1998), granulocyte-macrophage 
1991) and oxidative stress due to overexpression of copper zinc superoxide dismutase (Frendo et al., 2000a, 2001). The molecular mechanisms underlying trophoblast membrane fusion are poorly understood. Proteins involved in cell adhesion (cadherin 11) (Getsios and MacCalman, 2003) and cellcell communication (connexin 43) (Frendo et al., 2003a) are known to be directly involved. We recently demonstrated the direct involvement of syncytin I, a human endogenous retroviral envelope glycoprotein (Frendo et al., 2003b), and the presence of syncytin 2, restricted to some villous cytotrophoblasts (Malassiné et al, 2006).

Several studies suggest that hCG stimulates villous trophoblast differentiation by acting on the LH/CG-R (Shi et al., 1993; Cronier et al., 1994; Yang et al., 2003). This receptor, which has seven transmembrane domains, belongs to the superfamily of $G$ protein-coupled receptors (Pierce and Parsons, 1981; Loosfelt et al., 1989; McFarland et al., 1989; Minegishi et al., 1990). The LH/CG receptor gene has been cloned in pig, mouse, rat and human; in humans it is composed of 11 exons and 10 introns, and its coding region is over $60 \mathrm{~kb}$ long (Segaloff and Ascoli, 1993). HCG binding to its receptor activates adenylate cyclase, phospholipase $\mathrm{C}$ and ion channels, which in turn control cellular cAMP, inositol phosphates, $\mathrm{Ca}^{2+}$ and other secondary messengers (Gudermann et al., 1992; Hipkin et al., 1992).

The presence of LH/CG-R in human placenta was first described by Alsat (Alsat and Cedar, 1974) and has since been confirmed by other authors (Reshef et al., 1990; Lei and Rao, 1992). Inhibition of LH/CG-R expression by specific antisense oligodeoxynucleotides during cytotrophoblast culture results in time- and concentration-dependent inhibition of cytotrophoblast differentiation, showing that hCG, via its receptor, is an autocrine and paracrine regulator of human placental syncytiotrophoblast formation (Yang et al., 2003).

Most of the studies actually done, have used transfected cells with cDNA from LH/CGreceptor in rat or mouse models. In human, the characterization and the modulation of LH/CG-R expression during syncytiotrophoblast formation is poorly documented. Here we used the physiological model of cultured primary human trophoblasts (Kliman et al., 1986; Frendo et al., 2000b), in which isolated mononuclear cytotrophoblasts differentiate and fuse to form a syncytiotrophoblast, which secretes large amounts of hCG and other pregnancy-related hormones. We 
used various methodological approaches to characterize the hCG/LH receptor, and observed its downregulation during villous trophoblast differentiation. This was confirmed by in situ immunolocalisation of the hCG receptor in sections of human placenta.

\section{6} 7

\section{Placental tissue collection and trophoblast cell culture}

These studies were performed in agreement with our local ethics committee and with written informed consent of patients. Third trimester placentas were obtained immediately after iterative Caesarian section from healthy mothers delivered at 35-39 weeks of amenorrhea. First trimester placentas (7-12 weeks of gestation) were collected following legal voluntary interruption of pregnancy from women who gave their written informed consent. Cytotrophoblasts were isolated as previously described (Alsat et al., 1993). After sequential trypsin (0.25\%)/DNase I digestion followed by Percoll gradient centrifugation (Frendo et al., 2003a), the cells were further purified by negative selection to obtain a trophoblast preparation not contaminated by other cells, by using a monoclonal anti-human leukocytic antigen A, B and C antibodies (W6-32HL, Sera Lab, Crawley Down, UK) according to a published method (Schmon et al., 1991; Cronier et al., 2002). This antibody reacts with most cell types (e.g. macrophages, fibroblasts, extravillous trophoblasts) but not with villous cyto- or syncytiotrophoblast. Cytotrophoblasts were diluted to a final density of $2.7 \times 10^{6}$ cells in $3 \mathrm{ml}$ of minimum essential medium (MEM) containing 10\% fetal calf serum (FCS). Cells were plated in 60-mm plastic dishes (TPP, Trasadingen, Switzerland) and incubated at $37^{\circ} \mathrm{C}$ in $5 \% \mathrm{CO}_{2}$. Cytokeratin 7 immunocytochemistry was performed to confirm the cytotrophoblastic nature of the attached cells: about 95-98\% of the cells were positively stained.

\section{Hormone assay}

The hCG concentration was determined in culture medium after 24 and 72 hours of culture by using an enzyme-linked fluorescence assay (Vidas System, BioMerieux, Marcy l'Etoile, France) with a 
detection limit of $2 \mathrm{mU} / \mathrm{ml}$. The hPL concentration was determined in 4-fold-concentrated conditioned medium by using a method (Amerlex IRMA, Amersham Pharmacia Biotech) with a detection limit of $0.5 \mu \mathrm{g} / \mathrm{ml}$. All reported values are means \pm SEM of triplicate determinations.

\section{Immunohistochemistry}

106 Placental samples were obtained after first-trimester abortion. They were fixed by incubation in $4 \%$

107 formalin for 4 to $12 \mathrm{~h}$ at room temperature and then embedded in paraffin, dewaxed in xylene and 108 rehydrated in ethanol/water. Immunostaining was performed with a universal streptavidin-peroxidase 109 immunostaining kit (Peroxidase, Dako LSAB ${ }^{\circledR}+$ Kit, DAKO ${ }^{\odot}$, Glostrup, Denmark). Non-specific 110 binding was blocked by incubation for $5 \mathrm{~min}$ in a blocking reagent containing $3 \% \mathrm{H}_{2} \mathrm{O}_{2}$ and then in $1113 \%$ serum albumin in PBS for $30 \mathrm{~min}$. The sections were incubated with the primary antibody for 30 $112 \mathrm{~min}$ at room temperature. The primary antibodies (table 1) were polyclonal anti-human LH/CG-R 113 (LHR-K15, Santa Cruz Biotechnology Inc, CA, USA, at $2 \mu \mathrm{g} / \mathrm{ml}$ ), monoclonal anti-cytokeratin 7 114 (M7018, DAKO ${ }^{\odot}$, Glostrup, Denmark, at $1 \mu \mathrm{g} / \mathrm{ml}$ ), and polyclonal anti-hCG (A0231 against the beta 115 subunit of hCG, DAKO ${ }^{\odot}$, Glostrup, Denmark, at $2 \mu \mathrm{g} / \mathrm{ml}$ ). Sections were washed in PBS and 116 incubated with a biotinylated secondary antibody for $15 \mathrm{~min}$. They were then washed three times in 117 PBS and incubated with streptavidin conjugated to horseradish peroxidase for $15 \mathrm{~min}$. The sections 118 were washed in PBS and staining was detected by incubation for 30 seconds with the DAB (3,3'-

119 diaminobenzidine) chromogen. Controls were performed by incubating the sections with nonspecific 120 IgG at the same concentration as the primary antibody. Successive pre-adsorptions of LH/CG-R 121 antibody with trophoblastic cells in culture abrogate LH/CG-R immunodetection.

\section{Immunocytochemistry}

124 To detect desmoplakin, LH/CG-R, hCG, cytokeratin 7 and hPL, cultured cells were rinsed with PBS, 125 fixed and permeabilized in methanol at $-20^{\circ} \mathrm{C}$ for $8 \mathrm{~min}$. Alternatively, cultured cells were fixed with $1264 \%$ paraformaldehyde at $4^{\circ} \mathrm{C}$ for $20 \mathrm{~min}$. After washing once with PBS, the remaining free aldehyde 127 groups were blocked by adding $50 \mathrm{mM} \mathrm{NH,Cl}$ for $10 \mathrm{~min}$. A polyclonal anti-desmoplakin (AHP320,

128 Serotec, Oxford, UK at $2.5 \mu \mathrm{g} / \mathrm{ml}$ ), two polyclonal anti-LH/CGR (LHR-K15 and LHR-H50, Santa 
129 Cruz Biotechnology Inc, CA, USA, at $2 \mu \mathrm{g} / \mathrm{ml}$ ), two polyclonal anti-hCG (A0231, DAKO ${ }^{\odot}$, Glostrup,

130 Denmark at $2 \mu \mathrm{g} / \mathrm{ml}$ and SC-7821, Santa Cruz Biotechnology Inc, CA, USA at $2 \mu \mathrm{g} / \mu \mathrm{l}$ ), a monoclonal 131 anti-cytokeratin $7\left(\mathrm{M} 7018, \mathrm{DAKO}^{\odot}\right.$, Glostrup, Denmark, at $\left.2.6 \mu \mathrm{g} / \mathrm{ml}\right)$, or a polyclonal anti-hPL 132 (A0137, DAKO ${ }^{\odot}$, Glostrup, Denmark, at $1.6 \mu \mathrm{g} / \mathrm{ml}$ ) was then applied (table 1), followed by 133 fluorescein isothiocyanate-labeled goat anti-mouse $\mathrm{IgG}$, or fluorescein isothiocyanate-labeled goat 134 anti-rabbit IgG (Jackson Immuno Research, Baltimore, USA at 1:150), or Alexa 488-labeled donkey 135 anti rabbit (Molecular probes Inc, OR, USA at 1:400), or Texas red labeled donkey anti goat (Jackson 136 Immuno Research, Baltimore, USA at 1:400), or $\mathrm{Cy}^{\mathrm{TM} 3}$ goat anti-rabbit $\mathrm{IgG}$, as previously described 137 (Frendo et al., 2001). The controls, which consisted of omitting the primary antibody or applying the 138 non specific IgG of the same isotype, were all negative.

\section{$140 \quad$ Immunoblotting}

141 Cell extracts were prepared as previously described (Alsat et al., 1996). Protein (70 $\mu \mathrm{g})$ was 142 solubilized in RIPA (radioimmunoprecipitation) buffer (50 mM Tris, $150 \mathrm{mM} \mathrm{NaCl}, 1 \%$ Triton X100, $1431 \%$ deoxycholate, $0.1 \%$ SDS, $\mathrm{pH}: 8$ ), and stained markers were submitted to $7.5 \%$ SDS-PAGE and 144 transferred to nitrocellulose sheets. Membranes were immunoblotted with two polyclonal antibodies 145 against LH/CG-R, LHR-K15 (goat anti human, Santa Cruz Biotechnology Inc, CA, USA) and LHR146 H50 (rabbit anti human, Santa Cruz Biotechnology Inc, CA, USA) at $2 \mu \mathrm{g} / \mathrm{ml}$ each, and the specific 147 band was revealed by chemiluminescence (West Pico Chemiluminescent, Pierce, Rockford, IL, USA) 148 after incubation with an anti-goat or anti-rabbit peroxidase-coupled antibody (Jackson Immuno 149 Research, Baltimore, USA). To detect actin, cytokeratin 7, hCG and hPL, we proceeded as described 150 above, except that proteins were immunoblotted with rabbit polyclonal antibody at $0.7 \mu \mathrm{g} / \mathrm{ml}$ for actin 151 (Sigma-Aldrich, MO, USA), rabbit polyclonal antibody at $0.4 \mu \mathrm{g} / \mathrm{ml}$ for hCG and $0.32 \mu \mathrm{g} / \mathrm{ml}$ for $\mathrm{hPL}$ 152 (DAKO $^{\odot}$, Glostrup, Denmark) and mouse monoclonal antibody at $0.5 \mu \mathrm{g} / \mathrm{ml}$ for cytokeratin 7 153 (DAKO $^{\odot}$, Glostrup, Denmark). Successive pre-adsorptions of LH/CG-R antibody with trophoblastic 154 cells in culture abrogate LH/CG-R immunodetection in western-blot analysis. 
158 Protein G Plus-Agarose (Immuno precipitation Reagent, Santa Cruz Biotechnology Inc, CA, USA) was pre-mixed with a polyclonal antibody against human LHCG-R (K15, Santa Cruz Biotechnology

160 Inc, CA, USA), or without antibody. Cells (1.0 x 10\% /well) were seeded in six-well plates and cultured

161 as previously described. After 24 hours of culture, cells were washed with PBS and scraped free in

162 ice-cold RIPA buffer. After sonication, the cellular lysate and debris were separated by centrifugation

163 at $10000 \mathrm{~g}$ for $10 \mathrm{~min}$ at $4^{\circ} \mathrm{C}$. The supernatant was transferred to the protein G-anti-human LHCG-R

164 immunocomplex and incubated overnight at $4{ }^{\circ} \mathrm{C}$ on a rocker platform, followed by four washes in

165 RIPA buffer. Protein was eluted by heating at $60^{\circ} \mathrm{C}$ for $10 \mathrm{~min}$ in $1 \mathrm{X}$ electrophoresis sample buffer

166 (Bio-Rad laboratories, CA, USA). Aliquots were submitted to 7.5\% SDS-PAGE and transferred to

167 nitrocellulose membranes. Membranes were exposed to antibody as previously described, or the blots

168 were incubated with ${ }^{125} \mathrm{I}-\mathrm{hCG}$ at $10^{-11} \mathrm{M}$ (PerkinElmer Life and Analytical Sciences Inc. MA, USA)

169 for $16 \mathrm{~h}$ at $4^{\circ} \mathrm{C}$ in the absence or presence of excess unlabeled hCG at $10^{-6} \mathrm{M}$ (Organon SA, Puteaux,

170 France). The blots were washed with PBS containing $0.1 \%$ Tween 20, then dried. Bound ${ }^{125}$ I-hCG was

171 visualized by autoradiography and analyzed by Cyclone (Storage phosphorImaging System, Hewlett

172 Packard, France).

173

\section{RNA extraction}

175 Total RNA was extracted from trophoblastic cells after 24 or 72 hours of culture by using the Trizol 176 reagent (Invitrogen Life Technologies, CA, USA) and was stored at $-80^{\circ} \mathrm{C}$ or at $-20^{\circ} \mathrm{C}$ in $75 \%$ ethanol 177 until use. The total RNA concentration was determined at $260 \mathrm{~nm}$ and RNA integrity was checked in $1781 \%$ agarose gel. The relative LH/CG-R mRNA levels were determined by semi-quantitative reverse 179 transcriptase-polymerase chain reaction (RT-PCR). The transcript level was normalized to the actin 180 mRNA level (endogenous control). 
RNA samples were pretreated with DNAse I using the RQ1 RNase-Free DNase kit (Promega Inc, WI,

USA). Briefly, we used 5 units of RQ1 RNase-free DNase per 5 micrograms of RNA, we then added RQ1 RNase-free 10x reaction buffer and TE buffer. Mixture was incubated at $37^{\circ} \mathrm{C}$ for $30 \mathrm{~min}$ and the digestion was terminated by the RQ1 DNase stop solution. DNase was then inactivated by heating at $65^{\circ} \mathrm{C}$ for $10 \mathrm{~min}$.

188 Complementary DNA was synthesized from $5 \mu \mathrm{g}$ of total RNA. The reaction mixture had a final 189 volume of $20 \mu \mathrm{l}$ and contained $375 \mathrm{mM} \mathrm{KCl}, 250 \mathrm{mM}$ Tris- $\mathrm{HCl}(\mathrm{pH} 8.3), 15 \mathrm{mM} \mathrm{MgCl} 2,0.1 \mathrm{M}$ DTT, $19040 \mathrm{U}$ of RNAsin®, $200 \mathrm{U}$ of reverse transcriptase Superscript II (Invitrogen Life Technologies, CA, 191 USA), $10 \mathrm{mM}$ each dNTP and $200 \mathrm{ng}$ of random primers (Invitrogen Life Technologies, CA, USA). Mixture of total RNA, DTT and random primers was heat at $65^{\circ} \mathrm{C}$ for $5 \mathrm{~min}$. Annealing was run for 10 $\min$ at $25^{\circ} \mathrm{C}$ and primer extension for $50 \mathrm{~min}$ at $42^{\circ} \mathrm{C}$. An aliquot of the reaction mixture $(5 \mu \mathrm{l})$ was then made up to $45 \mu 1$ with Taq polymerase buffer containing 1 unit of Taq polymerase Platinium (Invitrogen Life Technologies, CA, USA). Before heating to $94^{\circ} \mathrm{C}$ (hot-start), 50 pmol of each specific primer was added. Amplification was run for 40 cycles for LH/CG-R and for 20 cycles for actin, consisting of $1 \mathrm{~min}$ at $94^{\circ} \mathrm{C}$ (denaturation), $1 \mathrm{~min}$ at $55^{\circ} \mathrm{C}$ (annealing) and $1 \mathrm{~min}$ at $72^{\circ} \mathrm{C}$ (extension). Oligonucleotide primers specific for the coding sequence of LH/CG-R (NM_000233) were used (Fig. 3A): P1 (+): 5'-CAAGCTTTCAGAGGACTTAATGAGGTC-3'; P1 (-): 5'-AAAGCACAGCAGTGG CTGGGGTA-3'; P2 (+): 5'-TCGACTATCACTTGCCTACC-3'; P2 (-): 5'-GGAGAAGACCTTCGTA ACAT-3'; Actin (NM_001101) (+): 5'-GTGGGGCGCCCCAGGCACCA-3'; Actin (-): 5'-CTCCTTA ATGTCACGCACGATTTC-3'. Amplified products were analyzed by electrophoresis on $1.8 \%$ agarose gels and visualized by ethidium bromide staining.

Cloning and DNA sequencing of LH/CG-R from trophoblastic cells

PCR products were eluted from agarose gel by using the Macherey Nagel kit (NucleoSpin Extract II, MN, Hoerdt, France) and purified DNA fragments were cloned into the pCRII-TOPO vector by using the TOPO-TA Cloning kit (Invitrogen Life Technologies, CA, USA). Positive clones were selected by PCR and were sequenced by Genome Express (Meylan, France). Both strands of DNA fragments were sequenced, using Ml3 reverse and Ml3 forward primers. 


\section{Intracellular cAMP determination}

214 Cells $\left(1.0 \times 10^{6} /\right.$ well $)$ were seeded in six-well plates and cultured as described above. After 24 h or 72 $215 \mathrm{~h}$, cells were preincubated with 10mM IBMX (3-isobutyl-1methylxanthine) for 1 hour to prevent 216 cAMP degradation and were stimulated for 20 min with $10^{-8} \mathrm{M}$ hCG (C6322, Sigma-Aldrich, MO, 217 USA). Cells were frozen on dry ice and cAMP was extracted with ice-cold $65 \%$ ethanol. The extracts 218 were dried and kept at $-20^{\circ} \mathrm{C}$ until use. Cyclic AMP was assayed after acetylation by using a method 219 (Amersham Biosciences, NJ, USA) based on the competition between unlabelled cAMP and a fixed 220 quantity of ${ }^{125}$ I-labelled cAMP for binding to a cAMP-specific antibody. Bound antibody was 221 separated from free fraction by magnetic separation with a second antibody Amerlex ${ }^{\mathrm{TM}}-\mathrm{M}$ preparation that is bound to magnetizable polymer particles. Separation of the antibody bound fraction is effected either by magnetic separation of the Amerlex ${ }^{\mathrm{TM}}-\mathrm{M}$ suspension or decantation of the supernatant. The concentration of unlabelled cAMP in the sample was then determined by interpolation from a standard curve.

\section{Binding assay and Scatchard analyses}

228 Trophoblastic cells $\left(1.0 \times 10^{6} /\right.$ well $)$ were seeded in six-well plates and cultured as described above. 229 After $24 \mathrm{~h}$ or $72 \mathrm{~h}$ of culture the cells were washed five times and cultured in DMEM, $0.1 \%$ BSA for 2 230 hours to dissociate any bound endogenous hCG. The cells were then washed and placed in $1 \mathrm{ml}$ of DMEM containing 0.1\% BSA and $1 \mathrm{mM}$ HEPES, $\mathrm{pH}$ 7.3. Cells were incubated for $30 \mathrm{~min}$ at room temperature with $0.5 \mathrm{nM}^{125} \mathrm{I}-\mathrm{hCG}$ and an increasing concentration of unlabelled hCG (from $10^{-12} \mathrm{M}$ to $10^{-8} \mathrm{M}, \mathrm{C} 6322$, Sigma-Aldrich, MO, USA) on a shaker platform at 50 cycles/min. At the end of the incubation period the cells were washed and scraped free, and bound radioactivity was counted. Each assay was performed in triplicate. Data were analyzed by using the LIGAND fitting program (version 4.97) (Munson and Rodbard, 1980). For Scatchard analysis, the results showing the number of labeled molecules associated with the cellular membrane were expressed in a number of molecule associated 
of culture after staining with DAPI, as previously described in the immunocytochemistry section. We 240 did not observe difference between the number of nuclei at $24 \mathrm{~h}$ and $72 \mathrm{~h}$ of culture (CT are non 241 proliferative cells and apoptosis or cellular loss account for about 4\% (data not shown).

$242{ }^{125}$ I-labeled hCG was prepared using chloramine T as oxidant (Hunter and Greenwood, 1962). In a 243 final volume of $20 \mu \mathrm{l}$, hCG $(5 \mu \mathrm{g}, 4.4 \mu \mathrm{M})$ was added to $0.5 \mathrm{mCi}$ of $\mathrm{Na}^{125} \mathrm{I}$ (Perkin-Elmer Life and 244 Analytical Sciences, MA, USA; $17.4 \mathrm{Ci} / \mathrm{mg}, 11.5 \mu \mathrm{M}$ ) neutralized with $0.1 \mathrm{M}$ Mops and poly(ethylene 245 glycol) $1000(1 \%)$. The reaction in $25 \mathrm{mM}$ Mops buffer $\mathrm{pH} 7.2$ was started by adding $100 \mu \mathrm{M}$ 246 chloramine-T for $3 \mathrm{~min}$ at room temperature and was stopped by adding $120 \mu \mathrm{M}$ sodium bisulfite for 3 $247 \mathrm{~min}$ and $2 \mathrm{mM} \mathrm{NaI}$ for $1 \mathrm{~min}$. The volume was then adjusted to $0.5 \mathrm{ml}$ with Mops-buffered saline (20 $248 \mathrm{mM}$ Mops, $130 \mathrm{mM} \mathrm{NaCl}, \mathrm{pH}$ 7.2) containing $1 \mathrm{mg} / \mathrm{ml} \mathrm{BSA}$. Iodinated-hCG was desalted on a PD10 249 Sephadex G25-M column in the same buffer. Specific activity of ${ }^{125} \mathrm{I}-\mathrm{hCG}$ was $2.1-2.4 \mathrm{Ci} / \mu$ mole 250 corresponding to about 1 atom of iodine per molecule hCG.

\section{Statistical analysis}

253 We used the StatView F-4.5 software package (Abacus Concepts, Inc., CA, USA). Values are reported 254 as means \pm SEM. Significant differences $(\mathrm{p}<0.05)$ were identified by analysis of variance (ANOVA).

\section{RESULTS}

\section{Human villous trophoblast differentiation in vitro}

260 We used the primary cell culture model of villous cytotrophoblasts isolated from term placenta 261 (Kliman et al., 1986; Alsat et al., 1991). Figure 1 shows purified cytotrophoblasts cultured on plastic dishes for 24 and 72 hours. Mononuclear cytotrophoblasts fused and formed multinucleated syncytiotrophoblasts, 72 hours after plating (Kliman et al., 1986). Syncytiotrophoblast formation was associated with a significant increase in hCG and hPL levels in the culture medium (Fig. 1 I).

265 Concomitantly, immunostaining for hCG (Fig. $1 \mathrm{~A}$ and B) and hPL (Fig. $1 \mathrm{~F}$ and $\mathrm{H}$ ) showed an 266 increase in intensity during in vitro syncytiotrophoblast formation. HPL, expressed mainly by the 
syncytiotrophoblast (Handwerger, 1991), was detected by immunostaining at $72 \mathrm{~h}$ (Fig. $1 \mathrm{D}$ and H)

but not at $24 \mathrm{~h}$ (Fig. $1 \mathrm{C}$ and F). Immunostaining of cytokeratin 7, expressed by trophoblastic cells (Blaschitz et al., 2000), was positive at $24 \mathrm{~h}$ (Fig. $1 \mathrm{C}$ and E) and $72 \mathrm{~h}$ (Fig. $1 \mathrm{D}$ and G).

These results showed that differentiation of isolated cytotrophoblasts into a syncytiotrophoblast is associated with an increase in the expression and secretion of hCG and hPL, hormones mainly synthesized by the syncytiotrophoblast.

\section{Decrease in $L H / C G-R$ protein levels during in vitro trophoblast differentiation}

As shown in figures $2 \mathrm{~A}$ and B, LH/CG-R was expressed by cultured cytotrophoblasts. The LH/CG-R immunostaining shown in this figure was obtained with the polyclonal antibody LHR-K15. Another antibody (LHR-H50) gave the same results (data not shown). LH/CG-R was expressed in both cytotrophoblasts $(24 \mathrm{~h})$ and syncytotrophoblasts $(72 \mathrm{~h})$, with punctuate immunolabeling. LH/CG-R immunostaining appeared stronger in cytotrophoblasts than in syncytiotrophoblasts. Double immunostaining for LH/CG-R (LHR-50) and hCG (C-20) of trophoblasts cultured for 48 hours (Fig. 2 $\mathrm{C}$ and D respectively, merge Fig. 2 E) illustrated the dynamics of the process. A mononucleated cytotrophoblast (Fig. $2 \mathrm{C}$ arrow head) expressed LH/CG-R, whereas aggregated trophoblasts showed and heterogenous immunostaining of both LH/CG-R and hCG (Fig. $2 \mathrm{E}$ ). To validate this observation, western-blot analysis was performed on extracts of cytotrophoblasts $(24 \mathrm{~h})$ and syncytiotrophoblasts (72 h) (Fig. $3 \mathrm{~A}$ ). At $24 \mathrm{~h}$ and $72 \mathrm{~h}$ of culture, two major bands with molecular masses (estimated from SDS gels) of 65-75 kDa and 85-95 kDa were observed, as described in other cellular models and in mammalian cells transfected with LH/CG-R cDNA. In the literature, the 85-95 kDa band corresponds to the mature LH/CG-R present at the cell surface, and the $65-75 \mathrm{kDa}$ band is the precursor of the cellsurface receptor (for review see Ascoli et al., 2002).

Our results show that the expression of the mature LH/CG-R and its precursor (respectively designated $\mathrm{m}$ and $\mathrm{p}$ in Fig. $3 \mathrm{~A}$ ) decreases during cytotrophoblast differentiation. At the same time, actin expression remains constant. Normalization of mature LH/CG-R protein expression to actin expression showed a significant decrease $(58.6 \pm 6.7 \%$; $\mathrm{p}<0.0001)$ in cell-surface receptor expression. We obtained similar results with the two antibodies used (LHR-K15 and LHR-H50). 
Interestingly, in the same cellular extracts, the decrease in precursor and mature LH/CG-R expression

296 coincided with an increase in hCG and hPL expression (Fig. 3 A).

297 To further characterize LH/CG-R expression during trophoblast differentiation, we performed 298 immunoprecipitation (IP) with anti-human LH/CG-R antibody (K15). Cellular extracts were purified 299 by immobilized anti-receptor antibody (IP) and eluates were analyzed by SDS-PAGE and 300 immunoblotting using the receptor-specific antibody (K15). A $90 \mathrm{kDa}$ band corresponded to the 301 mature form of LH/CG-R (m), and a major band of $75 \mathrm{kDa}$ corresponded to the precursor (p).

302 To determine which molecular form of the receptor bound the hormone, we used ${ }^{125}$ I-hCG in ligand303 blot experiments (Fig. 3 B). Incubation of the IP blot with ${ }^{125} \mathrm{I}-\mathrm{hCG}\left(10^{-11} \mathrm{M}\right)$ revealed a major band of $30490 \mathrm{kDa}$. This band was absent when the blot was incubated with an excess of unlabeled hCG $\left(10^{-6} \mathrm{M}\right)$, 305 showing that the $90-\mathrm{kDa}$ LH/CG-R specifically binds the hormone. In these conditions, ${ }^{125} \mathrm{I}-\mathrm{hCG}$ 306 binding to the mature form of the receptor $(90 \mathrm{kDa})$ was lower in the syncytiotrophoblast than in 307 cytotrophoblasts.

\section{Decrease in LH/CG-R mRNA expression during in vitro trophoblast differentiation}

310 We conducted semi-quantitative RT-PCR experiments with two different sets of primers (P1 and P2) 311 (for primer positions see Fig. 4 A). To avoid contamination by genomic DNA, each primer was 312 located on a separate exon and RNA extracts were pretreated with DNAse I.

313 As shown in figure $4 \mathrm{~B}$, amplification of the 647-bp and 282-bp fragments, obtained with primers P1 314 and P2 respectively, indicated that LH/CG-R mRNA was significantly less abundant in the 315 syncytiotrophoblast $(72 \mathrm{~h})$ than in cytotrophoblasts $(24 \mathrm{~h})$. No significant difference was noted in the 316 actin mRNA level. We obtained similar results with the two sets of primers. The amplification 317 products were then purified from the agarose gel and cloned into the pCRII-TOPO vector. Sequencing 318 confirmed that both the 647-bp and 282-bp fragments were part of the human LH/CG receptor.

319 Normalization of LH/CG-R mRNA to actin mRNA after RT-PCR with primer sets P1 and P2 showed 320 a significant decrease in LH/CG-R mRNA levels during differentiation (Fig. 4 C). With the P1 321 primers, $\mathrm{LH} / \mathrm{CG}-\mathrm{R}$ mRNA levels fell from $0.33 \pm 0.01$ at $24 \mathrm{~h}$ to $0.13 \pm 0.01$ at $72 \mathrm{~h}(\mathrm{p}<0.0001)$. A 322 similar decrease was observed with the P2 primers (from $0.82 \pm 0.02$ at 24 h to $0.36 \pm 0.01$ at $72 \mathrm{~h} ; \mathrm{p}<$ 

abundant as that obtained with primers P1 (probably because the P2 amplicon is about half the length of the P1 amplicon), the size of the decrease in LH/CG-R levels at $72 \mathrm{~h}$ was similar with the two primer sets (respectively 2.5- and 2.3-fold).

\section{Decrease in ${ }^{125}$ I-hCG binding to cell-surface LH/CG-R during in vitro trophoblast differentiation}

329 To confirm the decrease in LH/CG-R mRNA and protein levels, we performed binding saturation 330 experiments with iodinated hCG at $24 \mathrm{~h}$ and $72 \mathrm{~h}$ of culture (Fig. 5). Scatchard analysis of binding 331 data showed that the number of molecules bound per seeded cell at $24 \mathrm{~h}$ of culture (cytotrophoblasts) was $3511 \pm 693$. After differentiation, at $72 \mathrm{~h}$ of culture, this number fell significantly $(\mathrm{p}=0.02)$ to 929 \pm 583 . No significant difference in Kd values was observed between $24 \mathrm{~h}(0.5 \pm 0.1 \mathrm{nM})$ and $72 \mathrm{~h}$ $(0.4 \pm 0.1 \mathrm{nM})$.

\section{LH/CG-R stimulation during in vitro trophoblast differentiation}

In order to confirm the reduction in functional mature hCG receptor expression at the syncytiotrophoblast surface compared to the cytotrophoblast surface, we determined cAMP production in response to an effective hCG concentration for 20 min (Fig. 6). As cAMP is a second messenger for hCG signaling in trophoblastic cells, the decrease in LH/CG-R transcript and protein levels ought to be associated with a decrease in cAMP production. Determination of the most effective hCG

342 concentration was carried out by stimulating trophoblasts with $10^{-12} \mathrm{M}$ to $10^{-6} \mathrm{M}$ hCG; $10^{-8} \mathrm{M}$ hCG was 343 the most effective concentration (data not shown). As shown in figure 6, hCG-stimulated cAMP 344 production by trophoblasts was higher at $24 \mathrm{~h}$ than at $72 \mathrm{~h}$ of culture $(\mathrm{p}=0.0021)$. Trophoblast 345 stimulation by hCG $\left(10^{-8} \mathrm{M}\right)$ at $24 \mathrm{~h}$ of culture induced at least a 2-fold increase in cAMP production compared to the basal level $(\mathrm{p}=0.0016)$, but did not induce detectable cAMP production at $72 \mathrm{~h}$ of

347 culture $(\mathrm{p}=0.7644)$. In contrast, epinephrine (which stimulates camp production and is used as a 348 positive control) induced similar cAMP production at $24 \mathrm{~h}$ and $72 \mathrm{~h}$ of culture, indicating that the cells 349 were functional and that the decrease in cAMP production observed at $72 \mathrm{~h}$ was not due to a defective 350 cAMP pathway. 
352 These in vitro findings were confirmed by examining placental LH/CG-R expression in situ, on villous sections. First-trimester placenta was chosen because cytotrophoblasts are more abundant than at other stages of pregnancy and form a continuous layer.

LH/CG-R was detected in villous cytotrophoblasts and syncytiotrophoblasts. Use of a polyclonal antibody raised against the extracellular domain of human LH/CG-R showed that LH/CG-R is mainly expressed by the cytotrophoblast layer (Fig. 7 A). Weaker staining was observed in the syncytiotrophoblast (ST). LH/CG-R was also expressed by perivascular cells (VC) of the villous core. We obtained similar results with two other monoclonal antibodies (LHR 29 and LHR 1055) which recognize two different epitopes of the extracellular domain of LH/CG-R (Vuhai et al., 1990; Méduri et al. 1997) (data not shown). No staining was detected in negative control sections (Fig. 7 D). Interestingly, strong hCG immunostaining was observed in the syncytiotrophoblast (Fig. 7 B) while cytokeratin 7 was mainly located in the cytotrophoblast layer (Fig. 7 C). LH/CG-R decreases during cytotrophoblast differentiation into a syncytiotrophoblast.

\section{DISCUSSION}

By using several complementary methods and a well-characterized in vitro model of human villous trophoblast differentiation, we clearly observed that LH/CG-R mRNA and protein expression is lower in syncytiotrophoblasts than in cytotrophoblasts and that this down-regulation is associated with an apparent decrease of receptor activation by its specific hormone. These results differ from those of two previous studies published by CV. Rao, who described stronger expression of LH/CG-R in syncytiotrophoblasts than in cytotrophoblasts (Reshef et al., 1990; Lei and Rao, 1992). This divergence may come from the use of different tools. Anti-human LH/CG-R antibodies were not 
antibodies raised against the N-terminal part of the rat $\mathrm{LH} / \mathrm{CG}$ receptor. The amino acid sequence 380 identity between the rat and human receptors is $85 \%$, with the strongest similitude in the 381 transmembrane portion of the molecule and not in the N-terminal region (Segaloff and Ascoli, 1993). 382 Moreover, experiments involving radiolabeled probes, such as northern blotting and in situ 383 hybridization, used porcine cDNA with $88 \%$ sequence identity to the human sequence. In this study, 384 we cloned PCR fragments of the human hCG/LH receptor from villous cytotrophoblasts and used antibodies specific for the human receptor.

HCG, which is produced in large amounts by the syncytiotrophoblast, plays an important role in cytotrophoblast differentiation into syncytiotrophoblast. An increasing number of studies have investigated the central role of hCG and its receptor in the trophoblastic differentiation process. Many authors have described down-regulation of LH/CG-R expression by increasing concentrations of hCG. Indeed, exposure of ovarian or testicular cells expressing the endogenous LH/CG-R to a high concentration of hCG down-regulates cell-surface receptor expression. This coincides with a decrease in the abundance of LH/CG-R transcripts (Segaloff et al., 1990; Peegel et al., 1994; Hoffman et al., 1991; LaPolt et al., 1990; Hu et al., 1990). It is noteworthy in this respect that hCG is secreted in large amounts during syncytiotrophoblast formation. The decrease in cell-surface receptor expression was confirmed in our study by the clear decrease in cAMP production by the syncytiotrophoblast after stimulation by recombinant hCG. Interestingly, the decrease in cAMP production by the syncytiotrophoblast was not due to a loss of affinity or to weak binding between the receptor and its 398 hormone, as we found no difference in LH/CG-R Kd values between $24 \mathrm{~h}$ and $72 \mathrm{~h}$ of culture. 399 Moreover, Scatchard plots clearly showed that the maximum number of hCG molecules bound per seeded cell was significantly lower at $72 \mathrm{~h}$ of culture than at $24 \mathrm{~h}(\sim 74 \%)$. This result confirms the decrease of LH/CG-R ( 60\%) observed by western-blot analysis. The difference in LH/CG-R decrease (60\% versus $74 \%$ ) may be due to the technical approaches used for the purpose. By western-blot analysis, we quantified the mature form of the LH/CG-R in proteins from total cellular extracts. In 404 binding experiments, we used living cells, meaning that only the mature form of the LH/CG-R present 405 at the cell surface was quantified. Some mature forms internalized or present in the endosome might 406 not be accessible to ${ }^{125} \mathrm{I}-\mathrm{hCG}$. 
loss of responsiveness to $\mathrm{LH}$, the receptor being temporarily uncoupled from its Gs protein (Segaloff et al., 1990). We observed here that syncytiotrophoblast stimulation by recombinant $\mathrm{hCG}\left(10^{-8} \mathrm{M}\right) \mathrm{did}$ not induce detectable cAMP production although the cAMP pathway was functional as shown by epinephrine stimulation. This loss of responsiveness to recombinant hCG may thus be due in part to cell-surface receptor desensitization. $\mathrm{kDa}$ and $85-95 \mathrm{kDa}$ were expressed by cytotrophoblasts and by syncytiotrophoblasts. Immunoprecipitation experiments and ligand blot analysis confirmed that the 65-75 $\mathrm{kDa}$ band was the intracellular precursor of the cell-surface receptor and that the 85-95 $\mathrm{kDa}$ band corresponded to mature LH/CG-R present at the cell surface, as shown by its ability to bind specifically labeled ${ }^{125}$ I-hCG. Our results show that the expression of the mature LH/CG-R and its intracellular precursor decreased during cytotrophoblast differentiation. Furthermore, the precursor form seemed to be more strongly expressed than the mature form in trophoblastic cells. Most studies of these two forms of LH/CG-R have used mammalian cells transfected with the cDNA for the porcine, rat or human receptor (for review see Ascoli and al., 2002), but as shown here, primary cultured human trophoblasts may be an excellent model for studying the maturation of the intracellular precursor into the mature cell-surface protein. Recently, Pietila et al using transfection models have shown that regulation of the immature form into the mature form might considered be important in LH/CG-R expression (Pietila et al., 2005). In this study, we characterized for the first time, in a human physiological model, the expression and regulation of LH/CG-receptor. We demonstrate, both in situ and in vitro, that LH/CG$\mathrm{R}$ is expressed by human cytotrophoblasts and, albeit to a lesser extent, by the syncytiotrophoblast. LH/CG-R expression thus seems to be regulated during villous trophoblast differentiation, and this regulation may involve down-regulation of the receptor by its ligand. Abnormal regulation of this 431 process might be involved in trisomy 21 -associated pregnancies, in which we recently observed an 432 abnormal glycosylated form of hCG associated with defective syncytiotrophoblast formation (Frendo 433 et al., 2000b, 2004). Abnormal syncytiotrophoblast formation might lead to complications such as 434 preeclampsia and intrauterine growth retardation. 
Alsat E, Cedar L. 1974. Mise en évidence d'une fixation spécifique de gonadotrophine chorionique humaine radio-iodée dans les tranches de placentas humains. C. R. Acad. Sc. Paris 278:26652668.

Alsat E, Haziza J, Evain-Brion D. 1993. Increase in epidermal growth factor receptor and its messenger ribonucleic acid levels with differentiation of human trophoblast cells in culture. $\mathbf{J}$ Cell Physiol 154:122-128.

Alsat E, Mirlesse V, Fondacci C, Dodeur M, Evain-Brion D 1991. Parathyroid hormone increases epidermal growth factor receptors in cultured human trophoblastic cells from early and term placenta. J Clin Endocrinol Metab 73:288-294.

Alsat E, Wyplosz P, Malassiné A, Guibourdenche J, Porquet D, Nessmann C, Evain-Brion D 1996. Hypoxia impairs cell fusion and differentiation process in human cytotrophoblast, in vitro. $\mathbf{J}$ Cell Physiol 168:346-353.

Aplin J. 1991. Implantation, trophoblast differentiation and haemochorial placentation: mechanistic evidence in vivo and in vitro. J Cell Sci 99:681-692.

Ascoli M, Fanelli F, Segaloff DL. 2002. The lutropin/choriogonadotropin receptor, a 2002 perspective. Endocr Rev 23:141-174.

Benirschke K, Kaufmann P. 2000. Pathology of the human placenta. New-York: Springer-Verlag.

Blaschitz A, Weiss U, Dohr G, Desoye G. 2000. Antibody reaction patterns in first trimester placenta: implications for trophoblast isolation and purity screening. Placenta 21:733-741.

Bo M, Boime I 1992. Identification of the transcriptionnally active genes of the chorionic gonadotrophin beta gene cluster in vivo. J Biol Chem 267:3179-3184.

Boyd J, Hamilton W. 1970. The human placenta. Heffer and Sons, Cambridge.

459 Cronier L, Bastide B, Herve JC, Deleze J, Malassine A. 1994. Gap junctional communication during human trophoblast differentiation: influence of human chorionic gonadotropin. Endocrinology $135: 402-408$. 
Cronier L, Defamie N, Dupays L, Theveniau-Ruissy M, Goffin F, Pointis F, Malassiné A. 2002. Connexin expression and gap junctional intercellular communication in human first trimester trophoblast. Mol Hum Reprod 8:1005-1013.

Feinman MA, Kliman HJ, Caltabiano S, Strauss JF 3rd. 1986. 8-Bromo-3',5'-adenosine monophosphate stimulates the endocrine activity of human cytotrophoblasts in culture. J Clin Endocrinol Metab 63:1211-1217.

Frendo J-L, Cronier L, Bertin G, Guibourdenche J, Vidaud M, Evain-Brion D, Malassine A. 2003a. Involvement of connexin 43 in human trophoblast cell fusion and differentiation. J Cell Sci. $116: 3413-3421$.

Frendo J-L, Olivier D, Cheynet V, Blond J-L, Vidaud M, Rabreau M, Evain-Brion D, Mallet F. 2003b. Direct involvement of HERV-W Env glycoprotein in human trophoblast cell fusion and differentiation. Mol Cell Biol 23:3566-3574.

Frendo J-L, Guibourdenche J, Pidoux G, Vidaud M, Luton D, Giovangrandi Y, Porquet D, Muller F, Evain-Brion D. 2004. Trophoblast production of a weakly bioactive human chorionic gonadotropin in trisomy 21-affected pregnancy. J Clin Endocrinol Metab 89:727-732.

Frendo J-L, Thérond P, Bird T, Massin N, Muller F, Guibourdenche J, Luton D, Vidaud M, Anderson WB, Evain-Brion D. 2001. Overexpression of copper zinc superoxide dismutase impairs human trophoblast cell fusion and differentiation. Endocrinology 142:3638-3648.

Frendo J-L, Thérond P, Guibourdenche J, Bidart J-M, Vidaud M, Evain-Brion D. 2000a. Modulation of copper/zinc Superoxide Dismutase expression and activity with in vitro differentiation of human villous cytotrophoblast. Placenta 21:773-781.

Frendo J-L, Vidaud M, Guibourdenche J, Luton D, Muller F, Bellet D, Giovagrandi Y, Tarrade A, Porquet D, Blot P, Evain-Brion D. 2000b. Defect of villous cytotrophoblast differentiation into syncytiotrophoblast in Down's syndrome. J Clin Endocrinol Metab 85:3700-3707.

Garcia-Lloret MI, Morrish DW, Wegmann TG, Honore L, Turner AR, Guilbert LJ. 1994. Demonstration of functional cytokine-placental interactions: CSF-1 and GM-CSF stimulate human cytotrophoblast differentiation and peptide hormone secretion. Exp Cell Res. 214:46-54. 
Getsios S, MacCalman CD. 2003. Cadherin-11 modulates the terminal differentiation and fusion of human trophoblastic cells in vitro. Dev Biol 257:41-54.

491 Gudermann T, Birnbaumer M, Birnbaumer L. 1992. Evidence for dual coupling of the murine luteinizing hormone receptor to adenylyl cyclase and phosphoinositide breakdown and $\mathrm{Ca} 2+$ mobilization. Studies with the cloned murine luteinizing hormone receptor expressed in L cells. J Biol Chem 267:4479-4488.

Handschuh K, Guibourdenche J, Tsatsaris V, Guesnon M, Laurendeau I, Evain-Brion D, Fournier T. 2006. Human Chorionic Gonadotropin expression in human trophoblasts from early placenta: comparative study between villous and extravillous trophoblastic cells. Placenta in press.

Handwerger S. 1991. The physiology of placental lactogen in human pregnancy. Endocrinology 12:329-336.

Hipkin RW, Sanchez-Yague J, Ascoli M. 1992. Identification and characterization of a luteinizing hormone/chorionic gonadotropin (LH/CG) receptor precursor in a human kidney cell line stably transfected with the rat luteal LH/CG-R complementary DNA. Mol Endocrinol 6:2210-2218.

Hoffman YM, Peegel H, Sprock MJ, Zhang QY, Menon KM. 1991. Evidence that human chorionic gonadotropin/luteinizing hormone receptor down-regulation involves decreased levels of receptor messenger ribonucleic acid. Endocrinology 128:388-393.

Hoshina M, Boothby M, Hussa R, Pattillo R, Camel HM, Boime I. 1985. Linkage of human chorionic gonadotrophin and placental lactogen biosynthesis to trophoblast differentiation and tumorigenesis. Placenta 6:163-172.

Hu ZZ, Tsai-Morris CH, Buczko E, Dufau ML. 1990. Hormonal regulation of LH receptor mRNA and expression in the rat ovary. FEBS Lett 274:181-184.

Hunter WM, Greenwood FC. 1962. Preparation of iodine-131 labeled human growth hormone of high specific activity. Nature 194:495-496.

Keryer G, Alsat E, Tasken K, Evain-Brion D. 1998. Cyclic AMP-dependent protein kinases and human trophoblast cell differentiation in vitro. J Cell Sci 111:995-1004. 
Kliman H, Nestler J, Sermasi E, Sanger J, Strauss III J. 1986. Purification, characterization, and in vitro differentiation of cytotrophoblasts from human term placentae. Endocrinology 118:15671582.

LaPolt PS, Oikawa M, Jia XC, Dargan C, Hsueh AJ. 1990. Gonadotropin-induced up- and downregulation of rat ovarian $\mathrm{LH}$ receptor message levels during follicular growth, ovulation and luteinization. Endocrinology 126:3277-3279.

Lei ZM, Rao CV. 1992. Gonadotropin receptors in human fetoplacental unit: implications for hCG as an intracrine, paracrine and endocrine regulator of human fetoplacental function. Troph. Res

Loosfelt H, Misrahi M, Atger M, Salesse R, Vu Hai-Luu Thi MT, Jolivet A, Guiochon-Mantel A, Sar S, Jallal B, Garnier J, et al. 1989. Cloning and sequencing of porcine LH-hCG receptor cDNA: variants lacking transmembrane domain. Science 245:525-8.

Lu DL, Peegel H, Mosier SM, Menon KM. 1993. Loss of lutropin/human choriogonadotropin receptor messenger ribonucleic acid during ligand-induced down-regulation occurs post

Malassine A, Blaise S, Handschuh K, Lalucque H, Dupressoir A, Evain-Brion D, Heidmann T. 2006. Expression of the Fusogenic HERV-FRD Env Glycoprotein (Syncytin 2) in Human Placenta is Restricted to Villous Cytotrophoblastic Cells. Placenta in press.

McFarland KC, Sprengel R, Phillips HS, Kohler M, Rosemblit N, Nikolics K, Segaloff DL, Seeburg PH. 1989. Lutropin-choriogonadotropin receptor: an unusual member of the G protein-coupled

Méduri G, Charnaux N, Loosfelt H, Jolivet A, Spyratos F, Brailly S, Milgrom E. 1997. Luteinizing hormone/human chorionic gonadotropin receptors in breast cancer. Cancer Res. 57:857-864.

Midgley AR, Pierce GB, Denau GA, Gosling JR. 1963. Morphogenesis of syncytiotrophoblast in vivo: an autoradiographic demonstration. Science 141:350-351.

540 Minegishi T, Nakamura K, Takakura Y, Miyamoto K, Hasegawa Y, Ibuki Y, Igarashi M. 1990. Cloning and sequencing of human LH/hCG receptor cDNA. Biochem Biophys Res Commun 172:1049-1054. 
Morrish DW, Bhardwaj D, Dabbagh LK, Marusyk H, Siy O. 1987. Epidermal growth factor induces differentiation and secretion of human chorionic gonadotropin and placental lactogen in normal human placenta. J Clin Endocrinol Metab 65:1282-1290.

Morrish DW, Bhardwaj D, Paras MT. 1991. Transforming growth factor beta 1 inhibits placental differentiation and human chorionic gonadotropin and human placental lactogen secretion.. Endocrinology 129:22-26.

Munson PJ, Rodbard D. 1980. LIGAND: A versatile computerized approach for characterization of ligand-binding systems. Anal Biochem 107:220-239.

Muyan M, Boime I. 1997. Secretion of chorionic gonadotropin from human trophoblasts. Placenta $18: 237-241$.

Peegel H, Randolph J Jr, Midgley AR, Menon KM. 1994. In situ hybridization of luteinizing hormone/human chorionic gonadotropin receptor messenger ribonucleic acid during hormoneinduced down-regulation and the subsequent recovery in rat corpus luteum. Endocrinology 135:1044-1051.

Pierce JG, Parsons TF. 1981. Glycoprotein hormones: structure and function. Annu Rev Biochem 50:465-495.

Pietila EM, Tuusa JT, Apaja PM, Aatsinki JT, Hakalahti AE, Rajaniemi HJ, Petaja-Repo UE. 2005. Inefficient maturation of the rat luteinizing hormone receptor. A putative way to regulate receptor numbers at the cell surface. J Biol Chem 280:26622-26629.

Reshef E, Lei ZM, Rao CV, Pridham DD, Chegini N, Luborsky JL. 1990. The presence of gonadotropin receptors in nonpregnant human uterus, human placenta, fetal membranes, and decidua. J Clin Endocrinol Metab 70:421-430.

Richard R. 1961. Studies of placental morphogenesis I. Radioautographic studies of human placenta utilizing tritiated thymidine. Proc Soc Exp Biol Med 106:829-831.

Schmon B, Hartmann M, Jones CJ, Desoye G. 1991. Insulin and glucose do not affect the glycogen content in isolated and cultured trophoblast cells of human term placenta. J Clin Endocrinol Metab 73, 888-893. 
Segaloff DL, Ascoli M. 1993. The lutropin/choriogonadotropin receptor ... 4 years later. Endocr Rev 14:324-347.

Segaloff DL, Wang HY, Richards JS. 1990. Hormonal regulation of luteinizing hormone/chorionic gonadotropin receptor mRNA in rat ovarian cells during follicular development and luteinization. Mol Endocrinol 4:1856-1865.

Shi QJ, Lei ZM, Rao CV, Lin J. 1993. Novel role of human chorionic gonadotropin in differentiation of human cytotrophoblasts. Endocrinology 132:1387-1395.

Vuhai-Luuthi MT, Jolivet A, Jallal B, Salesse R, Bidart JM, Houllier A, Guiochon-Mantel A, Garnier J, Milgrom E. 1990. Monoclonal antibodies against luteinizing hormone receptor. Immunochemical characterization of the receptor. Endocrinology 127:2090-2098.

Yang M, Lei ZM, Rao ChV. 2003. The central role of human chorionic gonadotropin in the formation of human placental syncytium. Endocrinology 144:1108-1120.

\section{FOOTNOTES}

$\S$ These two authors contributed equally to the work.

* Corresponding author

We thank Dr Fanny Lewin for her support and the staff of the Saint Vincent de Paul Obstetrics Department for providing us with placentas. This work was supported by la Caisse d'Assurance Maladie des Professions Libérales Province. GP was supported by a fellowship from Conseil Regional d'Ile-de-France, and J-LF by a grant from INSERM (Projet Avenir). 
595 Fig. 1 In vitro human villous trophoblast differentiation. (A) and (B): hCG immunodetection after 24 and 72 hours of culture of villous cytotrophoblasts isolated from term placentas. At 24 hours the cells are sparse or aggregated (A). At 72 hours, they have fused to form the syncytiotrophoblast, characterized by multiple nuclei and a strong positive immunofluorescent staining for hCG (B). Nuclei were labeled with DAPI (blue fluorescence). (C) and (D): co-immunolocalization of cytokeratin 7 (in green) and hPL (in red) at 24 hours (C) and 72 hours of culture (D). Nuclei are stained blue with DAPI. HPL, known to be expressed mainly by the syncytiotrophoblast, was detected by immunostaining at $72 \mathrm{~h}(\mathbf{H})$ but not at $24 \mathrm{~h}$ of culture (F). Cytokeratin 7 immunostaining, was positive at $24 \mathrm{~h} \mathrm{(E)} \mathrm{and} 72 \mathrm{~h} \mathrm{(G).} \mathrm{(I):} \mathrm{levels} \mathrm{of} \mathrm{hCG} \mathrm{and} \mathrm{hPL} \mathrm{(expressed} \mathrm{respectively} \mathrm{in} \mathrm{milli-international}$ units per milliliter and micrograms per milliliter of medium) secreted into the culture medium at the indicated times. Since cells were plated in triplicate (see Experimental procedures), hCG and hPL levels were determinated for each plate. ND: non detectable. Results are means \pm SEM of the three culture dishes. This figure illustrates one experiment representative of three. Scale for pictures A-D: 1 $\mathrm{cm}=30 \mu \mathrm{m}$. Scale for pictures E-H: $0.5 \mathrm{~cm}=30 \mu \mathrm{m}$.

Fig. 2 LH/CG-R immunodetection during in vitro trophoblast differentiation. (A) and (B): immunostaining for LH/CG-R by using the polyclonal antibody LHR-K15 raised against the human LH/CG receptor. LH/CG-R was expressed in both cyto- (A; 24h) and syncytotrophoblasts (B; 72h), albeit more strongly in cytotrophoblasts. (E): co-immunodetection of LH/CG-R and hCG by using the polyclonal antibodies LHR-H50 (C; in green) and hCG-C20 (D; in red) respectively at 48 hours of culture. Single trophoblast (arrowed) was stained for LH/CG-R and aggregated trophoblasts were stained for both LH/CG-R and hCG. Nuclei were labeled with DAPI (blue fluorescence). Scale for

617 pictures $A$ and B: $0.5 \mathrm{~cm}=30 \mu \mathrm{m}$; scale for pictures C-E: $1 \mathrm{~cm}=15 \mu \mathrm{m}$. 
622 masses of 65-75 kDa, corresponding to the precursor (p) of the cell-surface receptor and 85-95 $\mathrm{kDa}$, corresponding to the mature LH/CG-R (m) present at the cell surface, were observed. The histogram presents the normalization of mature LH/CG-R protein expression $(\mathrm{m})$ by actin expression $(43 \mathrm{kDa})$ $(* * *: p<0.0001)$. Results are expressed as the mean \pm SEM of three culture dishes. In the same cellular extracts, decrease in precursor and mature LH/CG-R expression was concomitant with an increase in hCG (38kDa) and hPL (22 kDa) expression. (B): immuno-precipitation and ligand-blot analysis. Cellular extracts were purified by immobilized anti-receptor antibody. Eluates were analyzed by SDS-PAGE and immunoblotting using the receptor-specific antibody. A $90 \mathrm{kDa}$ band corresponding to the mature form of LH/CG-R (m) and a major band with a molecular mass of $75 \mathrm{kDa}$ corresponding to the precursor (p) were observed. Incubation of the IP blot with labeled ${ }^{125} \mathrm{I}-\mathrm{hCG}\left(10^{-}\right.$ ${ }^{11} \mathrm{M}$ ) revealed a major radioactive band at a molecular weight of $90 \mathrm{kDa}$, which was not detected when the blot was incubated with an excess of unlabeled hCG $\left(10^{-6} \mathrm{M}\right)$. Figures A and B illustrate one experiment representative of five.

Fig. 4 LH/CG-R mRNA expression during in vitro trophoblast differentiation. (A): diagram showing the seven transmembrane domains of the LH/CG-receptor and the location of the primers sets used in this study. The two sets of primers (P1 and P2) are located on the extracellular domain. P1 amplifies a fragment of 647-bp in the exons 2-9 and P2 amplifies a fragment of 282-bp in the exons 1-

640 5. (B): Ethidium bromide-staining gel of one representative of five independent experiments. Semiquantitative RT-PCR experiments with both the primers P1 and P2 shows respectively a 647-bp and a 282-bp amplified fragment. RT-PCR products were separated on $1.8 \%$ agarose gel and analysed by densitometry. Sequencing confirmed that both the 647-bp and the 282-bp fragments are part of the LH/CG receptor. (C): histograms represent the normalization of LH/CG-R mRNA by actin mRNA after RT-PCR with primers sets P1 (upper histogram) and P2 (lower histogram). Data are expressed as mean \pm SEM of five independent experiments similar to the one shown in B. bp: base pairs; ***: $\mathrm{p}<$ 0.0001 . 
649 Fig. 5 Scatchard analyses of ${ }^{125}$ I-hCG binding to trophoblasts during in vitro differentiation.

650 Binding was performed for 30 minutes at room temperature, on cells at 24 hours $(\square)$ or 72 hours (

651 of culture. The apparent dissociation constants $(\mathrm{Kd})$ and the maximum number of molecules bound per $652 \mathrm{mg}$ of protein at 24 hours and 72 hours of culture were calculated by the LIGAND program (lower 653 table). Results are expressed as the mean \pm SEM of three experiments.

654

655 Fig. 6 Intracellular cAMP production after LH/CG-R stimulation during in vitro trophoblasts 656 differentiation. Stimulation of cells at 24 hours and 72 hours of culture was performed with $10^{-8} \mathrm{M}$ of 657 hCG or with epinephrine (used as a positive control) for $20 \mathrm{~min}$ and compared to non stimulated cells 658 (0). **: $\mathrm{p}<0.005$ and $* * *: \mathrm{p}<0.0001$

659

660 Fig. 7 Immunolocalization of LH/CG-R, hCG and cytokeratin 7 in villous sections. (A): 661 immunohistochemical staining of LH/CG-R, using the polyclonal antibody (H50) raised against the 662 extracellular domain. Villous cytotrophoblasts (CT), syncytiotrophoblast (ST) and perivascular cells 663 (VC) of the villous core were positively stained. (B): a strong immunostaining of hCG was observed 664 in the syncytiotrophoblast. (C): immunostaining of cytokeratin 7 was mainly located in 665 cytotrophoblasts layer. (D): No staining was observed in control sections treated with non specific 666 isotypic immunoglobulins. 